\title{
PARASITOFAUNA OF BROWN BEAR (URSUS ARCTOS) IN THE PROTECTED LANDSCAPE AREA CHKO - POLANA
}

\author{
Orosová, T. ${ }^{1}$, Goldová, M. ${ }^{1}$, Ciberej, J. ${ }^{2}$, Štrkolcová, G. ${ }^{1}$ \\ ${ }^{1}$ Institute of parasitology \\ ${ }^{2}$ Institute of nutrition, dietetics and feed production \\ University of Veterinary Medicine and Pharmacy, Komenského 73, 04181 Košice \\ The Slovak Republic
}

maria.goldova@uvlf.sk

\section{ABSTRACT}

During the years 2015-2016 we obtained 15 samples of faeces of brown bears (Ursus arctos) and 2 samples of gastrointestinal (GI) tracts of young female brown bears for helminthological examinations. The samples of faeces were collected from various sites in the protected landscape area CHKO-Polana, and the gastrointestinal tracts originated from bears hunted down in the same area within permitted regulation of bear population for 2015. Of the 17 samples collected from the CHKOPolana area, 13 were positive for the presence of parasites $(76.47 \%)$. Parasitological examinations revealed the presence of 5 species of endoparasites: Eimeria, Cryptosporidium, Sarcocystis, Baylisascaris and Ancylostoma. Roundworms Baylisascaris transfuga (46.15\%) and Ancylostoma spp. (30.77\%) were the dominant species. Observation of the seasonal dynamics showed the highest prevalence of parasites during autumn and winter.
Key words: Ancylostoma; Baylisascaris transfuga; brown bear (Ursus arctos); Cryptosporidium; Eimeria; Sarcocystis

\section{INTRODUCTION}

The brown bear (Ursus arctos) is the most numerous large beast living in the Slovak territory. At the end of the 1920s, they were almost eradicated as their number decreased down to about 15-75 individuals. After the year 1932, when the State Protection of Nature of the Slovak Republic (SR) enacted a nationwide protection of this animal, the population of brown bears increased more than 40-fold. Between 2013-2015 the State Protection of Nature of SR set up a selection procedure for the implementation of a complex study of assessing of the population of brown bears (Ursus arctos) based on a non-invasive 
method of determination of DNA in samples of excrements and the population of brown bears in Slovakia was assessed to be $1256 \pm 233$ individuals. This animal is most numerous in the mountain chains Velká (Greater) Fatra and Malá (Lesser) Fatra, the Low Tatras, the High Tatras and Polana [12]. In 1981, Polana was declared a Protected Landscape Area $(\mathrm{CHKO})$ for the purpose of protecting plant and animal communities and non-living nature. It is located in central Slovakia where it spreads over 20,360 hectares [14].

The majority of information about endoparasites in bears comes from the North America and Canadian territories where there are several bear species (grizzly, Baribal, and other). Only sporadic information is available about parasitofauna of the brown bears in Slovakia. This study conducted during 2002-2003 showed that in the areas of Western, Low and Belianske Tatry the eggs of Baylisascaris transfuga and Toxascaris transfuga were found at the highest prevalence in brown bears [6]. The examination of samples of bear faeces collected in 2008-2009 in the area of National park Poloniny confirmed the highest prevalence of the species Baylisascaris transfuga $[1,10]$. The study conducted in 2010-2011 recorded 55.6\% prevalence of Cryptosporidium spp. in samples of brown bear faeces collected in central and eastern Slovakia [13]. This protozoan opportunistic pathogen with zoonotic potential is the causative agent of enteritis and diarrhoea in weakened individuals.

A special group of parasitoses are helminthoses, the most important of which are roundworms of the genus Baylisascaris, as well as species of the genus Ancylostoma. Larvae of these helminths cause larva migrans syndrome in humans, occurring in various forms (nervous, ocular, visceral). The infectious larva migrates in organs and tissues of humans which results in a wide scale of symptoms and raises serious risk to human health.

The aim of this study was to investigate the prevalence of endoparasites in brown bears in the Protected landscape area CHKO-Polana in relation to their potential risk to human health.

\section{MATERIALS AND METHODS}

From spring to winter in the years 2015-2016 we collected 15 samples of faeces of brown bear in the territory Protected Landscape Area (CHKO) Polana. We collected samples from different sites in order to decrease the pos- sibility of obtaining several samples from the same animal. We also obtained 2 gastrointestinal tracts from young (4-5 years) female bears hunted down within permitted regulation of brown bears in the hunting grounds of the Protected hunting area (CHPO) Polana used by the state enterprise Woodland of SR (LESY SR). They were subjected to complete helminthological examination.

The diagnostic methods employed in our study included the flotation method for the diagnosis of protozoan cysts and helminth eggs with the use of flotation solutions according to Breza and Faust [9]. To diagnose cryptosporidian oocysts in the faeces, we prepared smears and stained them by the Kinyoun method [4]. The samples were examined also by the ELISA method using the commercial kit Cryptosporidium ELISA (f. Diagnostic Automation, INC, Calabasas, CA). This ELISA is an in vitro immunoassay for the qualitative determination of Cryptosporidium antigen in faeces.

\section{RESULTS}

Of the total number of 17 samples (15 samples of faeces, 2 GI tracts) 13 were positive $(76.47 \%)$ for the presence of parasites. By means of the flotation method, we detected in one sample the presence of oocysts of the genus Eimeria $(7.69 \%)$, in 2 samples Sarcocystis spp. (15.38\%) and in 4 samples (30.77\%) eggs of the helminth Ancylostoma spp. The highest prevalence was observed for the species Baylisascaris transfuga (46.15\%) which was confirmed by total helminthological examination of the GI tract of two young female bears where we detected presence of both adult and juvenile forms of roundworms. The ELISA meth-

Table 1. Species composition and prevalence of endoparasites found in samples from brown bears in the Protected Landscape Area (CHKO) Pol'ana

\begin{tabular}{lc}
\hline \multicolumn{1}{c}{ Genus/Species } & Prevalence \\
\hline Cryptosporidium & $15.38 \%$ \\
Eimeria & $7.69 \%$ \\
Sarcocystis & $15.38 \%$ \\
Ancylostoma & $30.77 \%$ \\
Baylisascaris transfuga & $46.15 \%$ \\
\hline
\end{tabular}


Table 2. Prevalence of endoparasites in brown bear according to seasons

\begin{tabular}{lc}
\hline Season & Prevalence \\
\hline Spring & $33.33 \%$ \\
Summer & $66.67 \%$ \\
Autumn & $85.71 \%$ \\
Winter & $100 \%$ \\
\hline
\end{tabular}

od confirmed the cryptosporidium antigen in two samples (15.38\%) (Table 1).

The highest prevalence of endoparasites was recorded during autumn and early winter months (October-December). In autumn the prevalence was $85.71 \%$ while in early winter it reached $100 \%$. In the spring, the prevalence was low $(33.33 \%)$ and in the summer it increased 2-fold (66.67\%) (Table 2).

\section{DISCUSSION}

Detailed surveys of parasitofauna of brown bear has been conducted in various areas of North America and Canada. The most frequently found species were roundworms Baylisascaris transfuga, Trichinella spiralis, Uncinaria spp., and tapeworms of genera Diphylobotrium, Taenia. Other endoparasites such as; Echinostoma revolutum, Dirofilaria ursi, and ectoparasites Dermacentor andersoni and Arctopsylla spp. occurred only sporadically [15]. Between 2011-2013 in Canada, in the territories of Alberta and British Columbia, 7 various endoparasites were found in the American black bear Baribal (Ursus americanus) and grizzly bear (Ursus arctos horribilis): Baylisascaris transfuga, Dirofilaria ursi, Uncinaria rauschi, Uncinaria yukonensis, Taenia arctos and tapeworms with a zoonotic character, such as, Diphyllobothrium dendriticum and Diphyllobotrium nihonkaiense [1].

It has been suggested that the maximum size of the brown bear population acceptable for the entire total Slovak territory is about 700 bears which would correspond to 1,150 hectares of wooded area per one animal. This comes to about $23 \%$ of the Slovak territory where these animals are regularly found. The increased pressure of human activities on the natural environment, such as: tourism, pick- ing forest fruits, hunting, timber harvesting, new settlements and constant construction activities, results in the displacement of bears to populated areas and raises the risk of their contact with humans. Changed living conditions of wildlife and the considerable increase in the population of the brown bears in the recent years are factors supporting the transmission of propagative stages of protozoa and helminths which have the potential to produce diseases in humans, the so-called parasito-zoonoses $[6,10,11]$.

There is available only sporadic information about the parasitofauna of brown bears in the Slovak territory. Investigations of endoparasites in brown bears were carried out by Mituch in 1972 [11] who performed helminthological dissections of 24 bears and recorded the occurrence of five different species of helminths: Taenia hydatigena, Toxascaris transfuga, Trichinella spiralis, Thomix aerophilus and Aelustrongylus abstrusus. Goldová et al. detected the presence of 6 parasite species: Baylisascaris transfuga, Ancylostoma spp., Toxascaris spp., Cryptosporidium spp., Taenia spp. and Capilaria spp. [6]. During 2008-2009 coprological examinations showed the presence of 4 parasite species with the prevalence reaching $72.34 \%$. The dominant species was Baylisascaris transfuga [10].

The majority of authors investigating the seasonal dynamics of parasites in bears reported that the highest prevalence of endoparasites was recorded in autumn and the lowest in spring. Several explanations were suggested, why bears hibernate only for short time or not at all during the winter season: global warming and relatively warm winter months; disturbance of bears by people; either tourists or hunters; or hunting parties during the major pre-denning period [2].

Our observations of the seasonal dynamics of endoparasites in brown bears showed that their prevalence was the highest during autumn (85.71\%) and early winter months (100\%). The majority of authors investigating seasonal dynamics of parasites in bears reported that the parasites were most prevalent in autumn and the prevalence in spring was the lowest. In agreement with our results, Major et al. [10] in their coprological study in 2008-2009 also observed the highest prevalence of endoparasites in autumn and winter and the lowest one in spring. Study in grizzly bears (Ursus arctos horribilis) in Canada also showed a higher prevalence of gastrointestinal parasites in autumn than in spring and the presumed reason for such dynamics was the elimination of adult helminths from their bod- 
ies before denning and subsequent re-infection in spring, as bears limit uptake of food shortly before their "winter sleep" and evacuate their bowels [5]. Choquete et al. [8] similarly presumed that endoparasites were eliminated before denning. However, Frechette and Rau and Finnegan speculated that adult parasites die during winter months denning due to the lack of carbohydrates and are subsequently decomposed and absorbed, or eliminated in the first spring faeces $[2,3]$. We contemplated that the high prevalence of endoparasites in winter months observed in our study was related to a relatively warm 2015/2016 winter which resulted in a short period of denning or its complete absence and bears consumed food also during this period. During late summer and autumn, when bears form fat reserves important for winter denning, they enter the phase known as hyperphagia when the intensity of feed intake increases by $2-3$ fold compared to the normal activity during spring and summer and as a result of this, their body weight may increase by $30-35 \%$ [7]. This biological peculiarity of brown bears may be the reason behind the recorded higher prevalence of endoparasites in this animal during late autumn and the winter months.

\section{CONCLUSIONS}

All species of endoparasites identified in the samples of bear faeces or their gastrointestinal tract present danger to human health as they are classified as parasito-zoonoses, i.e. diseases that can naturally be transmitted to humans. Baylisascaris transfuga and Ancylostoma spp. are considered the potential causes of visceral, nervous or ocular form of larva migrans in mammals including man. In humans, particularly in immunodeficient patients, coccidia of Cryptosporidium spp., may cause serious infections with pronounced clinical symptoms, such as watery diarrhoea associated with colic and abdominal pain, nausea, weight loss, and even dehydration. The enormous increase in the bear population in Slovakia in the past several years; regular occurrence of bears close to populated areas; repeated encounters of these animals with people; increased pressure of human activities on natural environment; insufficient denning during winter months; and the possibility of transmission of infectious stages of protozoa and helminths, raise considerable risk to the health of the human population.

\section{ACKNOWLEDGEMENTS}

The study was supported by the grant of the State Agency VEGA No. 1/0455/15.

\section{REFERENCES}

1. Catalano, S., Lejeune, M., Tizzani, P., et al., 2015: Helminths of grizzly bears (Ursus arctos) and American black bears (Ursus americanus) in Alberta and British Columbia, Canada. Can. J. Zool., 93, 10, 765-772.

2. Finnegan, S., 2009: Seasonal Dynamics in the Prevalence of Baylisascaris transfuga ova in the faeces of the brown bear (Ursus arctos) in Slovakia. Diploma thesis, University of Veterinary Medicine and Pharmacy in Košice (ÚVIK UVL), 55 pp.

3. Frechette, J.L., Rau, M.E., 1978: Seasonal changes in the prevalence of ova of Diphyllobothrium ursi and Baylisascaris transfuga in the faeces of the black bear (Ursus americanus). Journal of Wildlife Diseases, 14, 342-344

4. Garcia, L.S., Bruckner, D.A., 1997: Diagnostic Medical Parasitology. 3rd edn., ASM Press, Washington, 937 pp.

5. Gau, R. J., Kutz, S., Elkin, B. T., 1999: Parasites in Grizzly Bears from the Central Canadian Arctic. Journal of Wildlife Diseases, 35, 3, 618-621.

6. Goldová, M., Ciberej, J., Rigg, R., 2003: Brown bear (Ursus arctos) and parasitic zoonoses (In Slovak). Folia Venatoria, 33, 123-127.

7. Hissa, R., 1997: Physiology of the European brown bear (Ursus arctos arctos). Ann. Zool. Fennici, 34, 267-287.

8. Choquette, L.P.E., Gibson, G. G., Pearson, A.M., 1969: Helminths of the grizzly bear, Ursus arctos L., in northern Canada. Can. J. Zool., 47, 167-170.

9. Letková, V., Čisláková, L., et al., 2010: Laboratory Diagnostic Methods in Veterinary Parasitology (In Slovak). University of Veterinary Medicine and Pharmacy in Košice (ÚVIK UVL), $110 \mathrm{pp}$.

10. Major, P., Molnár, L., Štofík, J., Goldová, M., 2009: Parasitofauna of the brown bear (Ursus arctos) in National park Poloniny (In Slovak). In School-Science-Practice I., University of Veterinary Medicine and Pharmacy in Košice, 318-322.

11. Mituch, J., 1972: Helminthfauna of carnivores in Slovak and Czech Republics (In Slovak). Folia venatoria, 2, 161-171.

12. Paule, L., Krajmerová, D., Bakan, J., 2016: How many bears live in Slovakia? (In Czech), Svět myslivosti (Hunter's World), $3,17,14-17$. 
13. Ravaszová P., Halánová, M., Goldová, M., Valenčáková, A., Malčeková, B., Hurníková, Z., Halán, M., 2011: Occurrence of Cryptosporidium spp. in red foxes and brown bear in the Slovak Republic. Parasitol. Res., 110, 469-471.

14. Šagát., M., Filo, J., et al., 1998: Pol’ana Above Detva (In Slovak). Book Centre., Žilina, SR, 101 pp.

15. Worley, D.E., Fox, J.C., Winters, J.B., Greer, K.R., 1974: Helminth and arthropod parasites of grizzly and black bears in Montana and adjacent areas. In Proceedings Third International Conference on Bears, Paper 45, New York, Intext Press, 455-464.
Selected paper from the 59th STUDENT SCIENTIFIC CONFERENCE, Section III - Food hygiene and the environment, held at the University of Veterinary Medicine and Pharmacy in Košice, SR, on April 6, 2016. 